\title{
The Effect of the Foot Reflection Therapy toward Systolic Blood Pressure in Patients with Primary Hypertension
}

\author{
Liota Marsha Renardiyarto, Dwi Ari Murti Widigdo, Tulus Puji Hastuti \\ Poltekkes Kemenkes Semarang \\ Email: liorenardiyarto@gmail.com
}

\begin{abstract}
Hypertension is a high blood pressure disorder which disrupts blood flow resulting in blocking of oxygen and nutrition carried by the blood to body tissue. Based on Dinas Kesehatan Jawa Tengah's data, hypertension became one of the health issues with a percentage of $37 \%$. One of non-pharmacological therapy is foot-reflexology therapy. This method gives a relaxation effect that could make blood circulating better, decay the blocking in blood vessel, nourish muscles and nerves, and strenghten heart activity. Objective: To determine the effect of foot reflection therapy toward systolic blood pressure in primary hypertension patient at Ngadirojo, Secang, Magelang Method: This study used the pre-experiment method with one group pre-test post-test design without a control group. Simple random sampling technic was used to get 46 subjects. Result: Wilcoxon Test result showed different significant in this study between pre-post test foot reflection therapy by $p=0.000(p<0.05)$. It meant there was an effect of foot-reflection therapy on systolic blood pressure in primary hypertension. The average of blood pressure decrease was $3,7 \mathrm{mmHg}$. Although, the results of this study showed that there was a significantly different decrease in this decrease was not clinically significant. The recommendation is made to conduct a study in a combination of pharmacology and non-pharmacology intervention to lower blood pressure.
\end{abstract}

Keywords: Blood pressure, foot reflection, hypertension. 
Liota Marsha: The Effect of the Foot Reflection Therapy

\section{Introduction}

Hypertension is a disease of high blood pressure in the blood vessels, as a result, the supply of oxygen and nutrients being blocked up to the body's tissues. High blood pressure causes the heart works harder to meet the body's needs, if this condition persists, it is referred to as high blood pressure disease (Rusdi \& Isnawati, 2009).

The World Health Organization (WHO) estimated that hypertension causes 9.4 million deaths and $7 \%$ of diseases in the world. The prevalence of hypertension in Indonesia was $31.7 \%$ of the population at the age of 18 years and over. Only $7.2 \%$ of the population had an understanding of hypertension, $0.4 \%$ took hypertension medications (Ministry of Health, Republic of Indonesia, 2012). According to data from the Central Java Health Office (2015) hypertension is one of the contributors to $37 \%$ health problems in general and also 63\% health problems such as infant mortality, diarrhea, leprosy, dengue fever, and HIV/AIDS. According to the data from the Magelang District Health Office in 2017, non-communicable diseases including hypertension is the highest incidence, with 17,018 patients. The number of patients with primary hypertension in the PHC Secang I was 1601 patients. Hypertension can cause comorbidities such as stroke, myocardial infarction, and chronic kidney disease (Masriadi, 2016).

The high prevalence of hypertension showed that hypertension requires proper management. Previous research found nonpharmacological therapy could reduce blood pressure in patients with hypertension. Nonpharmacological techniques include reducing stress, weight loss, reducing alcohol and cigarette consumption, exercise or physical activity, and relaxation (Muttaqin, 2014). Non-pharmacological treatments can be used as a complement to anti-hypertensive drugs (Dalimartha, Purnama, Sutarina, Mahendra \& Darmawan, 2008). Antihypertensive drugs are useful for lowering blood pressure, but when it used for long periods of time, several side effects may occur such as headaches, vertigo, angioedema, impotence and impaired kidney function (Kee \& Evelyn, 2012).

One relaxation technique that can be used as an alternative therapy for hypertension is foot reflexology. Foot reflection therapy provides benefits that reduce pain in the body, can also prevent various diseases, one of which is to treat high blood pressure (Wahyuni, 2014). Research conducted by Fauzan (2015) concluded that foot massage therapy using coconut shell is effective in lowering blood pressure. Another study by Rezky (2015) stated that foot reflection therapy lowers blood pressure. Reflection therapy in addition to relaxation techniques that can facilitate blood flow shed blockages in blood vessels, nourish muscles and nerves, and strengthen the work of the heart (Almuttaqin, 2018). The purpose of this study was to determine the effect of foot reflection therapy on systolic blood pressure in patients with primary hypertension. Foot reflection therapy is expected to be able to overcome hypertension problems.

\section{Research Method}

The design of this study was Pre Experimental; with one group pretest-posttest design. The population in this study was primary hypertensive patients in Ngadirojo Village, Secang District, Magelang Regency. Samples were taken randomly with a total of 46 respondents. The sample in this study was based on inclusion and exclusion criteria. Inclusion criteria were willing to participate, suffering from primary hypertension, and not taking hypertension drugs. The exclusion criteria were a history of heart, kidney, and stroke, and the condition worsened so that it was not possible to participate.

The researcher conducted a preliminary survey and sampling data. The intervention respondent group were invited to Ngadirojo Village, Secang District, Magelang Regency. The action includes 2 stages. In the first stage, respondents rested 15-30 minutes of blood pressure measurement with a sitting position 3 times and averaged, recorded on the blood pressure measurement data sheet, and then performed foot reflection therapy. Stage 2, the respondent is given a break for 15-30 minutes, blood pressure measurements are taken again with a sitting position 3 times and the average is calculated, and recorded on 
Liota Marsha: The Effect of the Foot Reflection Therapy

the observation sheet. Based on the normality test of the data using the Shapiro Wilk test, the results show an abnormal data $(p<0.05)$. Furthermore, statistical tests were performed using the Wilcoxon test.

\section{Research Results}

Table 1 shows that the percentage of males respondents was $54.35 \% \quad(n=25)$. Table 2 shows that the percentage of respondents age $44-53$ year was $30.43 \%(n=14)$. Table 3 presents the systolic blood pressure before therapy was $127 \mathrm{mmHg}$, and after therapy was $141.24 \mathrm{mmHg}$. Table 4 shows the hypothesis test found that $p<0.05$ means there was a significant relationship between foot therapy and systolic blood pressure.

\section{Discussion}

Characteristic of respondents found that 25 respondents were male $(54.35 \%)$, and female were 21 respondents $(45.65 \%)$. This finding in line with the theory of Applegate (1998) in Setyawati (2010) states that blood pressure tends to be higher in men than in women. This is due to higher renin activity in men than women. Different results in Kristina's study (2015) that found $88 \%$ of hypertensive patients were women.

The results showed that the age of most

Table 1 Frequency Distribution of Respondents' Genders

\begin{tabular}{lcc}
\hline \multicolumn{1}{c}{ Variable } & f & $\mathbf{P ( \% )}$ \\
\hline Males & 25 & 54.35 \\
\hline Females & 21 & 45.65 \\
Total & 46 & 100
\end{tabular}

Table 2 Frequency Distribution of Respondents' Ages

\begin{tabular}{lcc}
\hline \multicolumn{1}{c}{ Variable } & $\mathrm{f}$ & $\mathrm{P}(\%)$ \\
\hline $24-33$ & 5 & 10.87 \\
\hline $34-43$ & 10 & 21.74 \\
\hline $44-53$ & 14 & 30.43 \\
$54-63$ & 6 & 13.04 \\
$>63$ & 11 & 23.91 \\
Total & 46 & 100
\end{tabular}

Table 3 The Average of Systole High-Pressure Pre-Post the Foot Therapy

\begin{tabular}{lcccc}
\hline & Min & Max & Mean & Different \\
\hline TD pre & 127 & 189 & 141.24 & 3.7 \\
TD post & $\mathbf{1 2 4}$ & $\mathbf{1 8 4}$ & $\mathbf{1 3 7 . 7 2}$ &
\end{tabular}

Bivariate analysis

Table 4 Uji Wilcoxon

$\begin{array}{ll}\text { Median } & \text { Value p } \\ \text { (Min-Max) } & \end{array}$

\begin{tabular}{lll}
\hline Pre Therapy & $132.50(127-189)$ & 0.000 \\
Post Therapy & $129.50(124-184)$ &
\end{tabular}


Liota Marsha: The Effect of the Foot Reflection Therapy

hypertensive patients was $>44$ years old. This finding in accordance with a study conducted by Elrita et al. (2013) in moderate and severe hypertensive patients in Manado found that respondents with hypertension were at most $40-60$ years old $(53 \%)$. Aryuni's et al. (2009) study; in Ponorogo, showed that most respondents with hypertension were in the age group $54-55$ years $(50 \%)$. The two results of the study are in accordance with the results of the analysis of this study found that the majority of respondents were aged 44-53 years 30, 43\%. Anggraini (2009) said that after the age of 45 years the artery wall will be thickened due to the accumulation of collagen in the muscle layer so that the blood vessels will narrow. Blood through blood vessels is narrower than usual, as a result, blood pressure increases. In the elderly it is also caused by the sensitivity of the blood pressure regulator, the baroreceptor reflex begins to decrease. Kidney function, which is kidney blood flow and glomerular filtration rate decreases and causes hypertension (Kurniasi, 2011).

The results showed that there was a difference in the average systolic blood pressure before and after the intervention for four times. The systolic blood pressure was decreased by $3.7 \mathrm{mmHg}$. Rezky's study (2015) performed massage 3 times in a row also showed a decrease of $6.29 \mathrm{mmHg}$ of systolic blood pressure. Atmojo (2008) says reflexology is not good for everyday treatment because it would be damaged reflex nerve points. The Maulana (2016) study with 7 interventions showed differences in the mean of systolic blood pressure before and after the interventions, the difference was $24.61 \mathrm{mmHg}$. Zunaidi (2014) study showed different results, His research conducted 12 times intervention in patients who taking hypertension drugs. The study found the average systolic blood pressure reduction was $13.80 \mathrm{mmHg}$ from $164.70 \mathrm{mmHg}$ to $150.90 \mathrm{mmHg}$.

The results of this study are supported by Tarigan (2009) which states that massage therapy (massage/reflection) lowers blood pressure if it is done regularly. Therapy also lowers the levels of the hormone cortisol and decreases anxiety so that it has an impact on reducing blood pressure and improving body function.

The results showed that the significance test obtained $\mathrm{p}=0.000$ or $\mathrm{p}<0.05$. It was concluded that there was a significant effect of foot reflection therapy on systolic blood pressure in patients with primary hypertension in Ngadirojo Village, Secang District, Magelang Regency. Nonpharmacological therapy of foot reflection has a significant effect in reducing blood pressure. Foot reflection therapy can be used as an alternative intervention in patients with primary hypertension, especially lowering blood pressure. Nugroho's research (2012) showed that therapeutic massage is more effective for lowering blood pressure compared to hypnotherapy. Physiologically, Chanif (2016) states that foot reflexology therapy has a direct influence on the elasticity of blood vessel walls.

According to the results of this study, the average decrease in pre and postintervention was not too much due to the absence of a combination of consumption of anti-hypertensive drugs and reflection therapy. Respondents only received massage intervention, so that the effects of vasodilation caused only foot reflection therapy, a decrease in systolic blood pressure occurred, but a gradual and not optimal decline. Maulana (2015) conducted a reflection therapy study on hypertensive patients who consumed hypertension (amlodipine) drugs, the results showed a decrease in systolic blood pressure of $24.61 \mathrm{mmHg}$. Consumption of antihypertensive drugs and lower extremity massage therapy with lavender essential oil makes the decrease in blood pressure more optimal. This is because of the effects of vasodilation arising from massage therapy synergize with the vasodilating effect of the hypertension drug Calcium Chanel Blocker (amlodipine), so the blood pressure in the respondents decreases optimally.

\section{Conclusion}

According to the results of the study, the total respondents $(n=46) 25$ respondents of them were male and female as many as 21 respondents. The respondent age more than 44 years was 15 respondents $(30.43 \%)$. The 
Liota Marsha: The Effect of the Foot Reflection Therapy

systolic blood pressure before foot reflection therapy was $189 \mathrm{mmHg}$ (maximum) and $127 \mathrm{mmHg}$ (minimum), and a mean value was $141.24 \mathrm{mmHg}$. After the intervention, the maximum systolic blood pressure was $184 \mathrm{mmHg}$, the minimum value was 124 $\mathrm{mmHg}$, and the mean value was 137.72 $\mathrm{mmHg}$. There is an effect of foot reflection therapy on systolic blood pressure in patients with hypertension with a significance value of 0.000 . The results showed a decrease in blood pressure of $3.7 \mathrm{mmHg}$ and did not show normal blood pressure. This therapy is good for maintaining blood pressure.

\section{References}

Anggraini, et al. (2009). Faktor-faktor yang berhubungan dengan kejadian hipertensi pada pasien yang berobat di Poliklinik Dewasa Puskesmas Bengkinang Periode Januari-Juni 2008. Skripsi: Fakultas Kedokteran Universitas Riau. Diunduh pada tanggal 5 April 2018.

Chanif. (2016). Efektifitas terapi pijat refleksi kaki untuk menurunkan stress psikologis pasien yang dirawat di intensif. ISSN 2407918. Diunduh tanggal 16 Januari 2018.

Dalimartha, S., dkk. (2008). Care your self hipertensi. Jakarta: Penebar Plus.

Fauzan, F.N. (2015). Efektivitas latihan refleksi kaki dengan menggunakan tempurung kelapa terhadap tekanan darah pada penderita hipertensi primer. JOM, 2(2). Diunduh tanggal 15 Januari 2018.

Masriadi, H. (2016). Epidemiologi penyakit tidak menular. Jakarta: Trans Info Medika.

Maulana, F.H. (2016). Pengaruh terapi massase ekstremitas bawah dengan minyak essential lavender terhadap penurunan tekanan darah pada lansia di UPTD Griya Werdha Surabaya. Skripsi: Universitas Surabaya.

Muttaqin, A. (2014). Pengantar asuhan keperawatan klien dengan gangguan sistem krdiovaskuar. Jakarta: Salemba Medika.

Nugroho, I.A. (2012). Efektifitas pijat refleksi kaki dan hipnoterapi terhadap penurunan tekanan darah pada pasien hipertensi. Jurnal Ilmiah Kesehatan Keperawatan, 8(2).

Rezky, R.A. (2015). Pengaruh terapi pijat refleksi terhadap tekanan darah pada penderita hipertensi primer. $J O M, 2(2)$.

Rusdi dan Isnawati, N. (2009). Awas! Anda bisa mati cepat akibat hipertensi dan diabetes. Yogyakarta: Power Books (IHDINA).

Tarigan, E. (2009). Pengetahuan, sikap, dan tindakan lansia tentang pemanfaatan posyandu lansia dalam menunjang status gizi di Puskesmas Petisah Medan. Skripsi: Universitas Sumatera Utara. Diunduh 2 April 2018.

Wahyuni, S. (2014). Pijat refleksi untuk kesehatan. Jakarta Timur: Dunia Sehat.

World Health Organization. (2013). A global brief on hypertension silent KILLER, Global Public Health Crisis. Journal A Global Brief on Hypertension.

Zunaidi, A. (2014). Pengaruh pijat refleksi kaki terhadap penderita hipertensi di Klinik Sehat Hasta Therapetika Tugurejo Semarang. Prosiding Konferensi Nasional II PPNI Jawa Tengah 2010. 